\title{
Variation in Out-migration Timing and Estuary Reliance of "ocean-type" Chinook Salmon in the Fraser River Estuary, BC
}

\author{
David C. Scott ${ }^{1 \mathbf{3}}$, Lia Chalifour ${ }^{2}$, Misty MacDuffee ${ }^{3}$, Julia K. Baum ${ }^{2}$, and Scott G. Hinch ${ }^{\mathbf{1}}$ \\ ${ }^{I}$ Pacific Salmon Ecology and Conservation Laboratory, Faculty of Forestry, University of British Columbia, 2424 \\ Main Mall, Vancouver, BC V6T 1Z4, Canada \\ ${ }^{2}$ Department of Biology, University of Victoria, Victoria, BC V8W 2Y2, Canada. \\ ${ }^{3}$ Raincoast Conservation Foundation, Sidney, BC V8G 1P2, Canada.
}

Keywords: Pacific salmon, Chinook salmon, estuary, outmigration timing, juvenile salmon

Estuaries connect freshwater and ocean environments for Pacific salmon, providing important habitats during a crucial transition period for juveniles where feeding opportunities are abundant, and the risk of predation is relatively low. All Pacific salmon migrate through estuaries twice during their lifespan and many will reside for days to months during their downstream migrations (Healey 1982; Weitkamp et al. 2014; Moore et al. 2016). Chinook (Oncorhynchus tshawytscha) and chum salmon (O. keta) migrate downstream in their first year of life as fry are known to rear in estuaries, from a few days up to a few months for some Chinook populations (Levings et al. 1991; Volk et al. 2010; Carr-Harris et al. 2015).

The Fraser River estuary in British Columbia is home to a diverse assemblage of salmon populations, and juvenile salmon originating from throughout the watershed migrate through the estuary each year. Chinook, chum and pink (O. gorbuscha) salmon rely on tidal-marsh habitats in the estuary for rearing and feeding, particularly juvenile Chinook salmon with "ocean type" life history, which depend on these habitats for extended periods before ocean entry (Levy and Northcote 1982). Many Fraser populations of Chinook have experienced persistent declines in survival over the past several decades, but the South Thompson ocean-type population has increased (CTC 2018; Riddell et al. 2013; Ruff et al. 2017). Beamish et al. (2010) found that these individuals were arriving in the marine environment later than other populations and hypothesized that the late ocean entry timing was conferring a survival benefit to South Thompson Chinook.

Research in the Fraser estuary and other estuary systems across the Pacific Northwest have demonstrated the importance of estuary rearing for juvenile Chinook salmon with ocean-type life histories. In the Fraser, Levy and Northcote (1982) demonstrated high densities of Chinook rearing in tidal marsh channels and hypothesized that growth in the estuary was greater than upstream freshwater habitats. Moore et al. (2016) described estuaries as important stop-over habitats for juvenile salmon and found that in the Skeena estuary $25 \%$ of juvenile Chinook salmon spent at least 33d in the estuary. Larger Chinook salmon resided in the estuary for longer durations, growing at an estimated $0.5 \mathrm{~mm} \cdot \mathrm{d}^{-1}$, evidence that estuary residency provides growth opportunities (Moore et al. 2016). In the Columbia estuary McNatt et al. (2016) found many juvenile Chinook salmon remained in the marsh for 2-4 weeks and increased in fork length by $10-20 \mathrm{~mm}$, with an average growth rate of $0.53 \mathrm{~mm} \cdot \mathrm{d}^{-1}$. The ability for juvenile Chinook to grow quickly during this estuary residence period is incredibly important as size at ocean entry is thought to be a major determining factor in early marine survival (Woodson et al. 2013). Based on these previous studies it seems likely that growth occurring in estuary habitats is important to the early marine survival of oceantype Chinook in the Fraser River.

Our objective was to compare the outmigration timing, size, and estuary residence period among and within populations of juvenile ocean-type Chinook in the Fraser River estuary. Ocean type Chinook populations are thought to be reliant on estuaries for critical growth periods before ocean entry, therefore should be adapted to enter the estuary during peak productivity periods. Environmental conditions in the Fraser estuary vary considerably over the out-migration period, including salinity, turbidity and marsh productivity, therefore variation in out-migration timing and estuary residence will likely lead to variation in growth rates within and across populations for juvenile Chinook which contributes to variable size at ocean entry and may impact early marine survival.

We conducted an extensive juvenile salmon monitoring program throughout the Fraser River delta over three years (2016-2018), surveying at 36 sites that span the North, Main and South Arms of the river, and Roberts and Sturgeon Banks and encompass three habitat types using beach and purse seine, and fyke net methods. We sampled bi-weekly throughout the spring and summer season, starting in late March and extending until mid-July in 20162017, and expanded until mid-August in 2018.

We conducted fish surveys in intertidal and subtidal habitats using beach and purse seines. Beach seines are primarily deployed in intertidal marsh channels with sufficient depth and width to deploy the net. A $20 \mathrm{~m}$ long x 2

All correspondence should be addressed to D. Scott. 
$\mathrm{m}$ deep beach seine with a $2 \mathrm{~m}$ deep bag with $6.3 \mathrm{~mm}$ stretch mesh was deployed from a small boat using the roundhaul method. A purse seine was used in sandflat and eelgrass sites. The purse seine $(30 \times 3 \mathrm{~m}, 6.3 \mathrm{~mm}$ stretch mesh bunt, $12.7 \mathrm{~mm}$ stretch mesh wings), was set from a boat and towed for $1 \mathrm{~min}$. In 2017 we also studied three marsh sites using a fyke net method previously utilized in the Fraser estuary by Levy and Northcote (1982). Our net consisted of two wings (14 m x $2.4 \mathrm{~m} ; 1 / 4$ " mesh) and a trap box (1.2 m wide x $3.0 \mathrm{~m}$ long x $3.0 \mathrm{~m}$ high; 1/4"mesh). The net was set across a small marsh channel at high tide and passively captured fish as the tide fell before being pulled to the side of the channel when the water depth reached $0.5 \mathrm{~m}$ and all fish were removed.

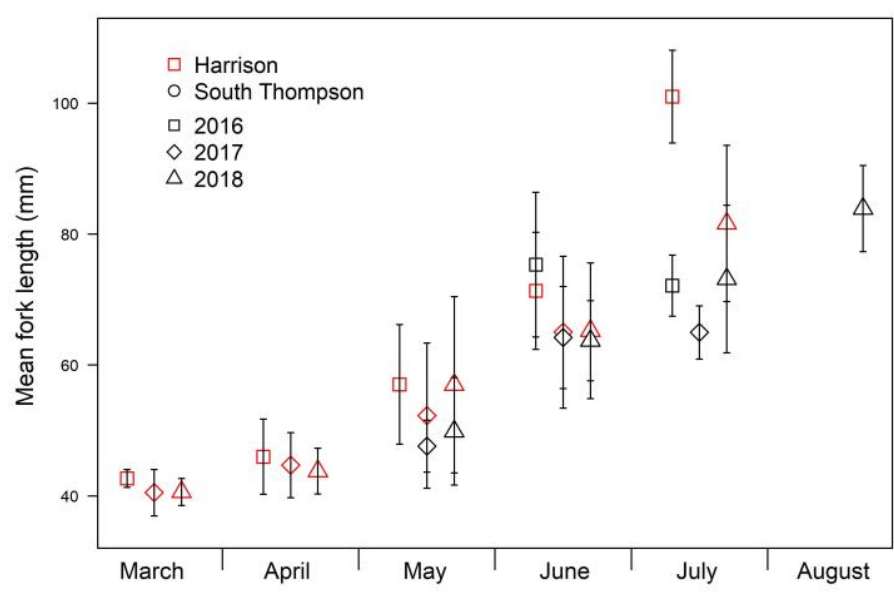

Fig. 1. Mean fork length and standard deviation for each month in each year of our study of juvenile Chinook salmon captured in the Fraser estuary, BC for which genetic stock identification was determined. Red symbols indicate Harrison River population and black symbols indicate South Thompson ocean type population. Squares represent averages from 2016, diamonds 2017 and triangles 2018.

We used genetic stock identification to determine the spawning location of origin of estuary-caught juvenile salmon. Samples were analyzed at the Pacific Biological Station by Fisheries and Oceans Canada by microsatellite DNA analysis which allows the identification of juvenile salmon to the population or Conservation Unit level.

Over three seasons (2016-2018) we captured 5,242 juvenile Chinook salmon, the majority in brackish marsh habitats, and have collected 1,696 tissue samples for genetic stock identification. Our initial results demonstrated that ocean-type Chinook originating from the Harrison River arrive in the estuary the earliest, near the end of March, and were present the longest until mid-July (Fig. 1). Harrison Chinook also arrived the smallest, with individuals increasing in mean fork length over the season, ranging from $35 \mathrm{~mm}$ to $77 \mathrm{~mm}$ (Fig. 1). Conversely, ocean-type Chinook from the South Thompson were not captured until late June in both years, ranging from $41 \mathrm{~mm}$ to $106 \mathrm{~mm}$ and last detected in August (Fig. 1). Overall, we captured juvenile Chinook from 18 different populations, and individuals from stream-type populations are generally captured in low numbers.

Our results confirm that ocean type Chinook salmon are the most estuary-reliant juvenile salmon in the Fraser estuary across the spring and summer outmigration period. Across three seasons we captured juvenile Chinook fry in the estuary from late March through until mid-August. This agrees with and extends the residence period noted by Levy and Northcote (1982) which demonstrated their presence into July. Genetic stock identification also allowed us to confirm that the early arriving Chinook fry almost entirely originated from the Harrison River population, and that individuals from this population were found in the estuary as late as July with fork length increasing over time. Our data also showed that although juvenile Chinook from the Harrison River were present in the estuary from late March until as late as July, the abundance peaks in late April and early May before quickly dropping off with relatively low abundance in late May and June. Therefore, although some juvenile ocean-type Chinook from the Harrison remained in the estuary for an extended period of time, the vast majority were likely only present for a few weeks, and this may be the first period of high mortality for this population. Regardless, these data demonstrate the continued direct importance of Fraser estuary habitats to this population of Fraser Chinook.

While our data confirm much of Levy and Northcote's (1982) work, our ability to utilize genetic stock identification revealed new insights into variation between and among ocean-type Chinook populations in the Fraser River. We demonstrated that juvenile ocean-type Chinook present in the estuary arrived in two separate waves, with Harrison River fry arriving from late March until June, and ocean-type Chinook from the South Thompson beginning to arrive in late May and early June. We found that by June and July, the majority of individuals captured 
were South Thompson Chinook, and they were the only individuals captured into August. These data also supported Beamish et al. (2010) which demonstrated similar trends in the marine environment of the Strait of Georgia. We found a difference in size between populations, with the majority of Harrison fry arriving to the estuary shortly after emerging from the gravel and were captured in large number at small sizes $(35-50 \mathrm{~mm})$ while the majority South Thompson fry arrived in the estuary at a larger size $(45-75 \mathrm{~mm})$ after a brief freshwater rearing period.

Our results provide important new insights into the variation in life history of juvenile Chinook salmon with ocean type life history types. Levy and Northcote (1982) demonstrated the ocean-type Chinook are the most estuary reliant species of juvenile salmon in the Fraser River and our data supports that conclusion. However, while they assumed one wave of juvenile Chinook which arrived in the estuary in early spring reared and grew in the estuary for several months, we demonstrate a second wave of ocean-type Chinook which appear later in the season in the same estuary habitats. Overall, our data demonstrates the large variability in early life history strategy both between and within populations of ocean-type Chinook salmon in the Fraser estuary. Further research to determine which life history strategies result in the greatest prospective of marine survival will aid our understanding of juvenile Chinook life history strategies and guide restoration targets for Fraser Chinook.

\section{REFERENCES}

Beamish, R.J., R.M. Sweeting, T.D. Beacham, K.L. Lange, and C.M. Neville. 2010. A late ocean entry life history strategy improves the marine survival of Chinook Salmon in the Strait of Georgia, 2010. N. Pac. Anadr. Fish Comm. Doc. 1282. 14 pp. (Available at https://npafc.org)

Carr-Harris, C., A.S. Gottesfeld, and J.W. Moore. 2015. Juvenile salmon usage of the Skeena River estuary. PLoS One. 10(3): e0118988.

CTC (Chinook Technical Committee). 2018. Annual Report of Catch and Escapement for 2017. Pac. Salmon Comm. Report TCCHINOOK (18)-2.

Healey, M.C. 1982. Juvenile Pacific salmon in estuaries: the life support system. In: Kennedy VS editor. Estuarine Comparisons. New York: Academic Press. pp. 315-341.

Levings, C.D., K. Conlin, and B. Raymond. 1991. Intertidal habitats used by juvenile Chinook salmon (Oncorhynchus tshawytscha) rearing in the north arm of the Fraser River estuary. Mar. Pollut. Bull. 22(1): 20-26.

Levy, D.A., and T.G. Northcote. 1982. Juvenile salmon residency in a marsh area of the Fraser River estuary. Can. J. Fish. Aquat. Sci. 39(2): 270-276.

McNatt, R.A., Bottom, D.L., and Hinton, S.A. 2016. Residency and movement of juvenile Chinook Salmon at multiple spatial scales in a tidal marsh of the Columbia River estuary. Trans. Am. Fish. Soc. 145(4): 774-785.

Moore, J.W., J. Gordon, C. Carr-Harris, A.S. Gottesfeld, S.M. Wilson, and J.H. Russell. 2016. Assessing estuaries as stopover habitats for juvenile Pacific salmon. Mar. Ecol. Prog. Ser. 559: 201-215.

Riddell, B., M. Bradford, R. Carmichael, D. Hankin, R. Peterman, and A. Wertheimer. 2013. Assessment of Status and Factors for Decline of Southern BC Chinook Salmon: Independent Panel's Report. Prepared with the assistance of D.R. Marmorek and A.W. Hall, ESSA Technologies Ltd., Vancouver, B.C. for Fisheries and Oceans Canada. (Vancouver. BC) and Fraser River Aboriginal Fisheries Secretariat (Merritt, BC). xxix + 165 pp. + Appendices.

Ruff, C.P., J.H. Anderson, I.M. Kemp, N.W. Kendall, P.A. Mchugh, A. Velez-Espino, and K. Rawson. 2017. Salish Sea Chinook salmon exhibit weaker coherence in early marine survival trends than coastal populations. Fish. Oceanogr. 26(6): 625-637.

Volk, E.C., D.L. Bottom, K.K. Jones, and C.A. Simenstad. 2010. Reconstructing juvenile Chinook salmon life history in the Salmon River estuary, Oregon, using otolith microchemistry and microstructure. Trans. Am. Fish. Soc. 139: 535-549.

Weitkamp, L.A., G. Goulette, J. Hawkes, M. O’Malley, and C. Lipsky. 2014. Juvenile salmon in estuaries: Comparisons between North American Atlantic and Pacific salmon populations. Rev. Fish. Biol. Fish. 24: $713-736$.

Woodson, L.E., B.K. Wells, P.K. Weber, R.B. MacFarlane, G.E. Whitman, and R.C. Johnson. 2013. Size, growth, and origin-dependent mortality of juvenile Chinook salmon Oncorhynchus tshawytscha during early ocean residence. Mar. Ecol. Prog. Ser. 487: 163-175. 